\title{
The impact of co-solvent application on the solvent refining process selectivity
}

\author{
Wpływ zastosowania współrozpuszczalnika na selektywność procesu rafinacji \\ rozpuszczalnikowej
}

\author{
Artur Antosz \\ Oil and Gas Institute - National Research Institute
}

\begin{abstract}
The performed studies involved solvent refining tests using a co-solvent for fractions of various viscosity classes, as well as reference processes with no participation of a co-solvent. The laboratory station used for the tests modelling the technological process enabled the performance of solvent refining processes in a continuous manner, simulating the industrial process used in the oil block of a petroleum refinery. Solvent refining tests of specific vacuum fractions used technological parameters adjusted to critical temperatures determined for the given arrangements. Basic physicochemical properties of the produced raffinates were determined. When analysing the results produced in laboratory extraction processes for NMP and NMP with a 5\% addition of formamide, for heavier fractions, there is a noticeable increase in the efficiency of raffinate by $3.4 \%(\mathrm{~m} / \mathrm{m})$ for a process using a co-solvent. However, it was characterised by a slightly lower viscosity index, lower refractive index and a slightly better colour. No differences were observed in the group composition of the compared raffinates; they were generally identical. In the case of lighter fractions, no increase in raffinate efficiency was noticed in a process using a co-solvent compared to a process conducted using just $\mathrm{N}$-methylpyrrolidone. The viscosity index was calculated for both processes at an identical level and it amounted to 119. A slight decrease in the refractive index and a colour improvement were recorded for a process which used NMP $+5 \%$ formamide. The group composition of the analysed raffinates exhibited a slight drop by $1.6 \%(\mathrm{~m} / \mathrm{m})$ in the paraffinic-naphthenic hydrocarbon content for the process using a co-solvent, and a $2.2 \%(\mathrm{~m} / \mathrm{m})$ increase in the level of aromatic hydrocarbons with a refractive index of $\mathrm{n}_{\mathrm{D}}{ }^{20}<1.53$.
\end{abstract}

Key words: solvent refining, solvent extraction, co-solvent.

STRESZCZENIE: W trakcie badań wykonano próby rafinacji rozpuszczalnikowej z zastosowaniem współrozpuszczalnika dla frakcji o różnej klasie lepkościowej oraz przeprowadzono procesy odniesienia bez udziału współrozpuszczalnika. Do badań modelujących proces technologiczny wykorzystano stanowisko laboratoryjne umożliwiające prowadzenie procesów rafinacji rozpuszczalnikowej W sposób ciągły, symulujące proces przemysłowy stosowany na bloku olejowym w rafinerii ropy naftowej. W próbach rafinacji rozpuszczalnikowej poszczególnych frakcji próżniowych użyto parametrów technologicznych dostosowanych do wyznaczonych temperatur krytycznych dla danych układów. Określono podstawowe właściwości fizykochemiczne wytworzonych rafinatów. Analizując wyniki uzyskane w laboratoryjnych procesach ekstrakcji NMP i NMP z dodatkiem 5\% formamidu, dla cięższej frakcji, można zauważyć wzrost wydajności rafinatu o 3,4\% $(\mathrm{m} / \mathrm{m})$ w przypadku procesu z zastosowaniem współrozpuszczalnika. Charakteryzował się on jednak nieco niższym wskaźnikiem lepkości, niższym współczynnikiem załamania światła i nieco lepszą barwą. W składzie grupowym porównywanych rafinatów nie zaobserwowano różnic, w zasadzie były identyczne. W przypadku lżejszej frakcji nie zauważono wzrostu wydajności rafinatu w procesie z zastosowaniem współrozpuszczalnika w stosunku do procesu prowadzonego z wykorzystaniem samego N-metylopirolidonu. Wskaźnik lepkości dla obu procesów obliczono na identycznym poziomie i wynosił 119. Niewielkie obniżenie współczynnika załamania światła oraz poprawę barwy odnotowano dla procesu, w którym zastosowano NMP $+5 \%$ formamidu. W składzie grupowym analizowanych rafinatów zaobserwowano niewielki spadek - o 1,6\% $(\mathrm{m} / \mathrm{m})$ zawartości węglowodorów parafinowo-naftenowych w przypadku procesu z udziałem współrozpuszczalnika oraz podwyższenie poziomu o $2,2 \%(\mathrm{~m} / \mathrm{m})$ węglowodorów aromatycznych o współczynniku załamania światła nD20 < 1,53.

Słowa kluczowe: rafinacja rozpuszczalnikowa, ekstrakcja rozpuszczalnikowa, współrozpuszczalnik.

Corresponding author: A. Antosz, e-mail: artur.antosz@inig.pl

Article contributed to the Editor: 09.02.2020. Approved for publication: 30.07 .2020 


\section{Introduction}

Processes utilising the selective action of solvents are used mainly during the refining of base oils and numerous other petroleum processing routines. Fractions generated during distillation under a lowered pressure may contain numerous unwanted components and contaminants. They include organic compounds containing sulphur, nitrogen and oxygen, inorganic salts and dissolved metals which were present in the feedstock. Moreover, vacuum distillates processed for the production of base oils also contain components negatively affecting the quality of final products of an oil block, which include polycyclic aromatic hydrocarbons and asphaltene-resin substances. The solvent refining process allows the removal of undesired components from distillates, using the variable solubility of hydrocarbons in organic solvents. Unlike paraffinic and naphthenic hydrocarbons, aromatic hydrocarbons are easily dissolved in the applied solvents. The solvent is mixed with feedstock in a continuous countercurrent process in a column extractor with spinning discs (Wiley, 2007).

Solvent extraction also favours corrosion prevention and protection of the catalytic converter in the subsequent base oil production processes. A key role in the process is played by the mass ratio of the solvent to the product undergoing purification, as well as the temperature of the process. The process of extraction is used in a classical oil block of an oil refinery, when converting vacuum distillates into base oils (Sequeira, 1992). The conceptual design of such a block is presented in Figure 1.

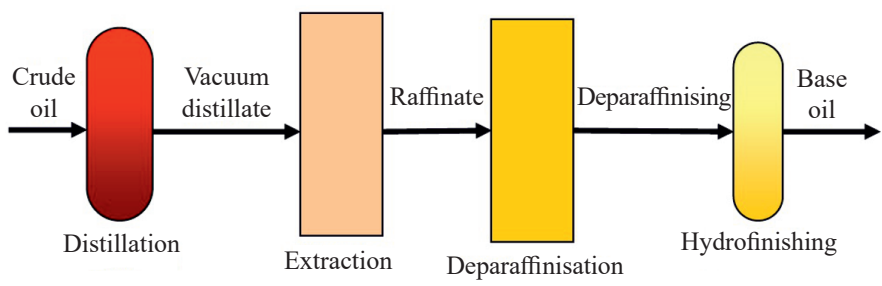

Fig. 1. Scheme for production of base oils in a classic oil block

Rys. 1. Schemat produkcji olejów bazowych w klasycznym bloku olejowym

\section{Solvent extraction processes}

The solvent extraction process is used when handling vacuum fractions and a DAO de-asphalter. The process involves separating undesired aromatic particles from hydrocarbon particles having a positive impact on the quality of base oil. It removes substances with a low viscosity index which expedite oil ageing processes, as well as substances with a high coke content. A selective solvent refining process uses its selective ability to dissolve these substances.
A stream of raffinate containing large amounts of hydrocarbons with a positive impact on oil quality is received from the refining column, along with a stream of extract which contains undesired aromatic hydrocarbons with a low viscosity index. An optimal solvent should be characterised by excellent solubility of aromatic hydrocarbons contained in the processed fraction, while having low or zero solubility of paraffinic and isoparaffinic hydrocarbons. Also, a difference in density between the solvent and the raffinate is desirable in order to facilitate the separation of phases inside the column (the solvent should have higher density). The low boiling point of the solvent facilitates the recovery of solvent in the regeneration process of a raffinate and extract solution. After the regeneration process, the resulting raffinate undergoes further processes of the oil block, while the extract may serve as feedstock for the generation of a plasticiser used in the production of rubber, or it is redirected to cracking (Sequeira, 1989).

The solubility of hydrocarbons in solvents used in the extraction process drops from aromatics, through naphthenes, to paraffins. An increase in temperature leads to an increase in the solubility of hydrocarbons in the solvent, and therefore a decrease in its selectiveness. Exceeding a certain temperature called the critical solution temperature KTR triggers the phenomenon of complete dissolution of fractions in a solvent. Near this temperature the solvent loses its selective properties (Pillon, 2007).

An increase in the extraction temperature is followed by an increase in the viscosity index, a decrease in viscosity, an increase in solidification temperature, a decrease in the coke content, a colour improvement, a drop in the refractive index with a simultaneous decrease in raffinate efficiency. An increase in the furfural to feed ratio leads to an increase in the viscosity index while reducing the raffinate recovery; however, there changes are definitely smaller than during changes in the temperature of the process (Pillon, 2007).

Generally, the boiling range of raffinate in relation to the resulting distillate does not change. When the boiling range of the vacuum fraction is too wide during a refining process with the defined operating parameters of an extraction column, this results in the so-called "overrefining" of the lightest components and "underrefining" of the heaviest components making up the vacuum fraction. For this reason the width of the fraction undergoing the refining process has a considerable impact on the operating conditions of a solvent refining installation and the course of the production process of base oils in an oil block (Speight, 2015).

As a result of the performed extraction process, desired hydrocarbons remain in the raffinate solution, i.e. paraffinic, isoparaffinic, naphthenic and aromatic hydrocarbons with one ring and long alkyl substituents, while highly condensed 
aromatic hydrocarbons, heterocyclic compounds and resins migrate to the extract solution (Bartyzel, 2012).

Table 1 presents desired hydrocarbons in base oils and particles of compounds which are removed or reduced during the refining process.

The raffinate recovery, meaning the efficiency of the process, is inseparably associated with the degree of refining. There is a general rule of solvent extraction: the more overrefined the oil, the lower the efficiency of the raffinate, but the properties of the raffinate undergo a general improvement. However, it should be noted that an increase in the quality of raffinate along with the degree of refining proceeds up to a certain threshold, reaching an optimum, and the quality of the raffinate is subsequently lowered. In order to secure adequately high efficiency of the raffinate with its proper quality, optimal parameters for performing the process are to be selected experimentally. Improvement of the properties of refined oil fractions is to an extent dependent on the properties of the original feedstock (petroleum), as well as the type of solvent used. Because base oils generated in refineries differ considerably in terms of their molecular composition and physical properties resulting from the parameters of the processed petroleum, each refinery must perform individual detailed tests of the selected fraction of lubricant oil, as well as laboratory tests of the adjustment of parameters of the solvent refining process to the required quality characteristics of the resulting base oils (Gary and Handwerk, 2001; Lynch, 2008).

All over the world, the refining of vacuum distillates in industrial extraction processes commonly uses three selective solvents: furfural, N-methylpyrrolidone and phenol. Each solvent used in the refining process must be immiscible with the oil base to the greatest possible extent, and preferably dissolve undesired hydrocarbons. Moreover, solvents used in extraction must be characterised by (Pillon, 2007; Bartyzel, 2011a):

- high density;

- the lack of a tendency to form emulsions;

- the absence of properties causing the corrosion of metals;

- low boiling point;

- satisfactory thermal stability.

Over the years, the refining of oil fractions converted into oils used various selective solvents like liquid $\mathrm{SO}_{2}$, nitrobenzene, aliphatic ketones, cresols, phenol, furfural and others. Until recently, phenol and furfural were the most commonly used solvents. Furfural is currently used in Poland. Although liquid sulphur dioxide and nitrobenzene are characterised by good selective properties, the critical temperature of the arrangements of these solvents with fractions is too low, preventing their wide use for the extraction of oil fractions with a high solidification temperature. Another very important disadvantage of liquid sulphur dioxide involves its high toxicity. N-methylpyrrolidone exhibits a high potential for the dissolution of aromatic hydrocarbons, high selectiveness, better chemical and thermal stability, as well as lower toxicity compared to furfural or phenol, and it requires less corrosion protection. It can be used for the refining of vacuum fractions from oils of both the paraffinic and the naphthenic types. Moreover, NMP is an appealing alternative to furfural for the extraction of feedstocks with high viscosities, which are characterised by low susceptibility to refining or require high solvent to oil ratios. Also, it has been concluded that, when using $\mathrm{N}$-methylpyrrolidone, the value of temperature during the refining process has more impact on selectiveness compared to other solvents (Tanasescu and Rosca, 2001; Abdul-Halim and Amal Khalid Shehab, 2008; Yousef and Ahmed Muhammad, 2018). 
Studies comparing solvent refining processes with furfural and N-methylpyrrolidone were performed in the Oil and Gas Institute - National Research Institute in 2010. As a result of these studies involving vacuum fractions acquired from the REBCO pipeline oil available on the domestic market, the possibility of a comparable quality level of raffinates has been confirmed for the use of softer technological parameters of NMP refining processes compared to extraction processes using furfural. This would allow reduction of the operating costs as a result of lowering the solvent to feedstock ratio and using lower operating temperatures for the extraction column, while retaining the required level of quality of base oils (Bartyzel, 2010; 2011a, 2011b, 2012; Pelc et al., 1988, 1989].

\section{Extraction processes using a co-solvent}

In solvent extraction processes, a single solvent may not have all the properties required for fully optimising the action of the solvent during the process. This is especially true when it exhibits a high potential for the solubility of aromatic hydrocarbons and separation of hydrocarbons. The use of cosolvents in extraction processes is a general way of increasing the selectiveness of solvent extraction and increasing the concentration of aromatic hydrocarbons in the resulting extract when refining vacuum fractions processed for the production of base oils (Fakhr Hoseini et al., 2009a; Antosz and Ptak, 2018).

The use of N-methylpyrrolidone in the processes of selective refining of vacuum fractions has forced the use of a co-solvent in the form of water. The use of water in industrial processes of refining vacuum fractions using $\mathrm{N}$-methylpyrrolidone allows increases in the critical temperature of solubility, and therefore an increase in the operating temperatures of the refining column, thus enabling performance of the process for vacuum fractions with a high solidification temperature. There is also an observed positive impact of added water on the selectiveness of the solvent (Fakhr Hoseini et al., 2009b).

In solvent extraction processes, in order to increase the efficiency of the process and its selectiveness, it is possible to add a second solvent, also known as the co-solvent. In a liquidliquid extraction process, the co-solvent may increase the efficiency of extraction in two ways (Hussein et al., 2014; Epelle et al., 2016):

- acting parallel to the primary solvent;

- acting opposite to the primary solvent.

In the first case, the co-solvent is additive in relation to the extract and it increases the efficiency of extraction by creating an extract-solvent complex. In the second case, the solvent is additive in relation to the raffinate. In this case, the second solvent increases the efficiency of extraction by creating a raffinate- solvent complex, and the mixture reaches its equilibrium within a shorter time. A very advantageous impact on the selectiveness of an extraction process using a co-solvent results from higher solubility of the used co-solvent in one of the phases of the extract or the raffinate (Ibtehal and Muslim, 2015; Luo et al., 2018).

A paper from 2018 (Yousef and Ahmed Muhammad, 2018) describes studies on the improvement of NMP selectiveness in a one-stage extraction process of a middle vacuum distillate acquired from petroleum produced in Egypt. Various co-solvents such as water, methanol, formamide, ethanol and ethylene glycol were added to NMP which was the primary solvent in order to maximise the raffinate recovery while maintaining the required quality parameters. The tests were performed for various parameters of the extraction process, such as the solvent composition to feedstock ratio, which ranged between $1: 1$ and $2: 1$, as well as various concentrations of the co-solvent ranging between $0 \%$ and $20 \%$.

An increase in the concentration of five tested co-solvents raises the efficiency of raffinate and has a positive impact on quality parameters, such as: the density viscosity of oil, sulphur content, refractive index, colour, solidification temperature and average molecular mass. The best results were produced with the use of formamide as a co-solvent in the extraction process with a concentration of $15 \%(\mathrm{~m} / \mathrm{m})$ in NMP; this arrangement produced a satisfactory compromise between the efficiency of the resulting raffinate and its quality. The results of the test also prove that an increase in the solvent composition to feedstock ratio resulted in a drop in the efficiency of raffinate, accompanied by an increase in the quality (lower sulphur content and refractive index) and in the efficiency of the resulting extract (Yousef and Ahmed Muhammad, 2018).

Data on the liquid-liquid balance in a system of immiscible liquids, and especially the determination of critical temperatures, are necessary to design extracting devices and calculate the thermodynamic threshold of a given process (Espada et al., 2008).

Studies involving the selectiveness of ion exchange with the participation of a co-solvent indicated that the use of an addition of light hydrocarbon compounds may increase extraction efficiency for aromatic compounds (Fakhr Hoseini et al., 2009b).

A patent from 2003 (Patent US2003100813) presents an improved solvent extraction process using furfural for vacuum distillates processed for the production of base oils by adding a co-solvent to the main solvent. The co-solvent function was best served by aliphatic amides or mixtures of amides added to the primary solvent. The tests indicated that the addition of a co-solvent facilitates the separation of phases, improves selectiveness and increases the efficiency of raffinate, at the same time maintaining its quality at a constant level, as confirmed by measurements of the refraction index of raffinate. A 5\% increase in raffinate efficiency was reached for a solvent 
to feedstock ratio of $1.8: 1$, while maintaining the same value of the refractive index for the raffinate. There are also other available patents involving the use of co-solvents in the extraction process (Patent US2010243533; Patent CN105542834; Patent IN39MU2014).

Other performed studies involved the use of 2,2,4-Trimethylpentane as a co-solvent with furfural for the extraction of aromatic hydrocarbons from vacuum distillates (Yousef and Ahmed Muhammad, 2018).

Raman and his co-authors (Patent US2010243533) suggested the use of formamide as a co-solvent with $\mathrm{N}$-methylpyrrolidone in order to increase the efficiency of extraction by over $6 \%$ by weight in relation to raffinate produced using just N-methylpyrrolidone. The applied co-solvent was chosen during research involving the introduction of a co-solvent from the group of amides to solvent extraction (Patent US2010243533). In the same year, studies on the improvement of properties were performed for base oils made from vacuum distillates in the Al Daura refinery. The main focus of the research involved increases in raffinate efficiency recovery. The tests used various solvent compositions consisting of furfural and N-methylpyrrolidone mixed in various proportions. The best results were produced for compositions containing from $80 \%$ to $60 \%$ furfural and from $20 \%$ to $40 \%$ $\mathrm{N}$-methylpyrrolidone. During these tests, the viscosity index went up to 114 and the refractive index decreased along with an increase in the efficiency of raffinate (Ghafil, 2010).

The paper called Extraction of Aromatic Hydrocarbons from Lube Oil Using Different Co-Solvent presented studies performed on the impact of the addition of a co-solvent on the solvent extraction process. In the presented paper, formamide and N-methylpyrrolidone used as co-solvents mixed with furfural in various proportions were used in a one-stage solvent extraction. The research results produced by the authors indicate that the viscosity index of base oil fractions increases, while viscosity and the efficiency of raffinate as a percentage decrease along with an increase in extraction temperature, the solvent/oil ratio and the cosolvent/furfural ratio (Ibtehal and Muslim et al., 2015).

In the scientific literature of the industry, there are also available papers on the use of co-solvents in the process of extraction of highly aromatic oil fractions used to generate a plasticiser for the production of rubber. One example of such a publication is a 2018 paper (Luo et al., 2018) describing studies performed in China regarding solvent extraction using furfural as the primary co-solvent for removing polycyclic aromatic compounds (PCA) from highly aromatic oil fractions. In order to increase the selectiveness and efficiency of the product resulting from the process, water was introduced as a co-solvent and its impact on the extraction process was examined. Determinations were made regarding the impact of the water content of furfural on the efficiency of the resulting raffinate, the polycyclic aromatic compound content, the distribution and amount of carbon atoms in the individual structures. The studies proved that it is possible to increase the raffinate recovery by $9 \%$ by selecting a proper furfural to water ratio in two-stage refining processes, while keeping the quality of the product at an acceptable level. The tests used a mathematical model meant to predict the composition of the product after extraction. The performed studies confirmed a satisfactory compliance of predictions of the computational model with experimental results from the laboratory station.

\section{Characteristics of studied feedstocks}

The tested feedstocks included two fractions, lighter and heavier, resulting from the distillation of atmospheric residue. Table 2 presents the physicochemical properties of feedstocks intended for laboratory-scale tests of solvent refining processes. The lighter fraction sample was labelled with the code 79/Bl, while the heavier fraction sample was labelled with the symbol 80/B1.

Table 2. Characteristics of the $79 / \mathrm{Bl}$ and $80 / \mathrm{Bl}$ fractions designated for investigation

Tabela 2. Charakterystyka frakcji 79/Bl i 80/Bl przeznaczonej do badań

\begin{tabular}{|l|c|c|}
\hline \multicolumn{1}{|c|}{ Assay type } & Lighter fraction (79/BI) & Heavier fraction (80/BI) \\
\hline \hline Density in a temp. of $70^{\circ} \mathrm{C}\left[\mathrm{kg} / \mathrm{m}^{3}\right]$ & 875.1 & 891.1 \\
\hline Kinematic viscosity in a temp. of $100^{\circ} \mathrm{C}\left[\mathrm{mm}^{2} / \mathrm{s}\right]$ & 6.357 & 13.199 \\
\hline Kinematic viscosity in a temp. of $50^{\circ} \mathrm{C}\left[\mathrm{mm}^{2} / \mathrm{s}\right]$ & 30.55 & 88.60 \\
\hline Viscosity index & 69 & 73 \\
\hline Refractive index in a temp. of $70^{\circ} \mathrm{C}$ & 1.4814 & 1.4981 \\
\hline Colour & 3.0 & $\mathrm{D} 8.0$ \\
\hline Sulphur content $[\%(m / m)]$ & 1.62 & 1.82 \\
\hline Group composition $[\%(m / m)]$ & & 41.6 \\
- paraffin-naphthenes & 50.3 & 23.7 \\
- aromatics with $\mathrm{n}_{\mathrm{D}}{ }^{20}<1.53$ & 16.2 & 5.6 \\
- aromatics with $\mathrm{n}_{\mathrm{D}}{ }^{20} 1.53-1.55$ & 11.7 & 16.0 \\
- aromatics with $\mathrm{n}_{\mathrm{D}}{ }^{20} 1.55-1.59$ & 9.1 & 4.0 \\
- aromatics with $\mathrm{n}_{\mathrm{D}}{ }^{20}>1.59$ & 6.7 & 8.2 \\
\hline - resins & 5.5 & 41 \\
\hline Solidification temperature $\left[{ }^{\circ} \mathrm{C}\right]$ & 30 & \\
\hline
\end{tabular}




\section{Solvent refining research station}

The large laboratory stations used in the technological tests enabled the performance of solvent refining processes, simulating the industrial process used in the oil block of a petroleum refinery.

The process of selective refining using $\mathrm{N}$-methylpyrrolidone or N-methylpyrrolidone with the participation of a vacuum distillate co-solvent was performed in a continuous manner in a large laboratory column.

Segments of the column were electrically heated with the ability to smoothly adjust the temperature. NMP or NMP with a co-solvent were fed to the top of the column with feedstock at its bottom by means of a dispensing laboratory plunger pump.

The total load of the column with the feedstock and the solvent was maintained at a constant level. A raffinate solution was received from the top of the column, with an extract solution at the bottom of the column. In order to distil off solvents from raffinate solutions, a distillation process was performed with stripping using overheated water vapour.

The efficiency of the extraction column corresponds to 7 theoretical degrees of extraction.

The performance of the raffinate and extract were calculated relative to the amount of feedstock - the input for refining.

\section{Laboratory processes of continuous refining}

In order to determine technological parameters for the performance of extraction processes, critical temperatures were determined for each fraction with specific solvent compositions. It was decided to adjust temperatures in which the processes were performed, taking into account critical temperatures determined for all laboratory tests.

Table 3. Parameters for refining processes of 79/B1

Tabela 3. Parametry dla procesów rafinacji frakcji 79/B1

\begin{tabular}{|l|c|c|}
\hline Parameters of the refining process & $\begin{array}{c}\text { For an arrangement } \\
\text { with NMP }\end{array}$ & $\begin{array}{c}\text { For an arrangement } \\
\text { with NMP + formamide }\end{array}$ \\
\hline \hline Solvent to feedstock ratio & $2.5: 1$ & $2.5: 1$ \\
\hline Column top temperature & $73^{\circ} \mathrm{C}$ & $108^{\circ} \mathrm{C}$ \\
\hline Column bottom temperature & $50^{\circ} \mathrm{C}$ & $85^{\circ} \mathrm{C}$ \\
\hline Column load & $3 \mathrm{~kg} / \mathrm{h}$ & $3 \mathrm{~kg} / \mathrm{h}$ \\
\hline
\end{tabular}

Table 4. Parameters for refining processes of $80 / \mathrm{Bl}$

Tabela 4. Parametry dla procesów rafinacji frakcji 80/Bl

\begin{tabular}{|l|c|c|}
\hline Parameters of the refining process & $\begin{array}{c}\text { For an arrangement } \\
\text { with NMP }\end{array}$ & $\begin{array}{c}\text { For an arrangement } \\
\text { with NMP + formamide }\end{array}$ \\
\hline \hline Solvent to feedstock ratio & $3.0: 1$ & $3.0: 1$ \\
\hline Column top temperature & $88^{\circ} \mathrm{C}$ & $117^{\circ} \mathrm{C}$ \\
\hline Column bottom temperature & $65^{\circ} \mathrm{C}$ & $94^{\circ} \mathrm{C}$ \\
\hline Column load & $3 \mathrm{~kg} / \mathrm{h}$ & $3 \mathrm{~kg} / \mathrm{h}$ \\
\hline
\end{tabular}

Tables 3 and 4 present the established refining process parameters for both fractions for processes with one solvent and an arrangement containing $5 \%$ of a co-solvent.

\section{Assessing the impact of the used co-solvent additive on the efficiency and quality of the resulting raffinates}

During the performance of the solvent refining process, the work of the laboratory refining column was uninterrupted; the extraction process had a proper course, which could be observed based on the separation of phases between NMP solutions of the raffinate and the extract through a sight glass placed in the central part of the extraction column, presented in Figure 2.

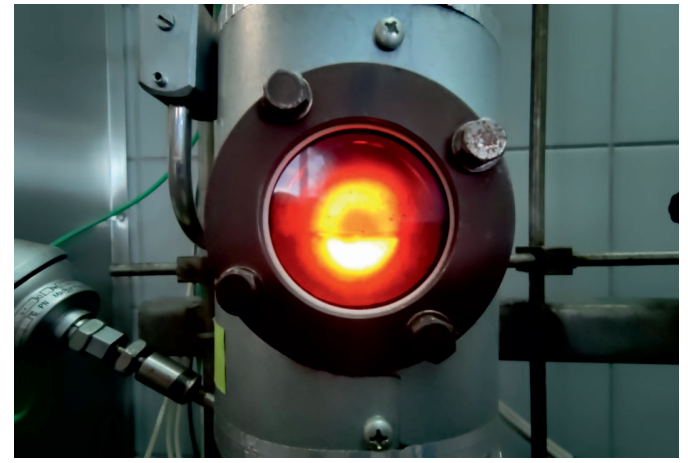

Fig. 2. A sight glass enabling the observation of phase separation inside the laboratory extraction column

Rys. 2. Wziernik umożliwiający obserwację rozdziału faz wewnątrz laboratoryjnej kolumny ekstrakcyjnej

The laboratory examinations of extraction processes for fractions $79 / \mathrm{Bl}$ and $80 / \mathrm{Bl}$, using $\mathrm{N}$-methylpyrrolidone as the main solvent and formamide as a co-solvent, allowed the generation of samples of raffinates and extracts. Raffinate samples underwent an assessment of physicochemical properties within a scope typical of raffinates. The properties of raffinates generated during processes using $\mathrm{N}$-methylpyrrolidone with no cosolvent were a point of reference for the assessment of the remaining raffinates created during refining processes using a co-solvent.

Table no. 5 lists the properties of raffinate samples resulting from laboratory tests.

When comparing the results produced in laboratory extraction processes for NMP and NMP with a 5\% addition 
Table 5. Properties of the obtained raffinates

Tabela 5. Właściwości uzyskanych rafinatów

\begin{tabular}{|c|c|c|c|c|}
\hline Laboratory raffinate & R 1378 & R 1379 & R 1380 & R 1381 \\
\hline \multicolumn{5}{|l|}{ Conditions of refining } \\
\hline feedstock & $80 / \mathrm{Bl}$ & $80 / \mathrm{Bl}$ & 79/B1 & 79/B1 \\
\hline solvent & NMP & $\mathrm{NMP}+5 \%$ formamide & NMP & $\mathrm{NMP}+5 \%$ formamide \\
\hline NMP to feed ratio & $3.0: 1$ & $3.0: 1$ & $2.5: 1$ & $2.5: 1$ \\
\hline column top/bottom temperature $\left[{ }^{\circ} \mathrm{C}\right]$ & $88 / 65$ & $117 / 94$ & $73 / 50$ & $108 / 85$ \\
\hline column load [kg/h] & 3 & 3 & 3 & 3 \\
\hline - raffinate efficiency calculated per feed $[\%(\mathrm{~m} / \mathrm{m})]$ & 33.4 & 36.8 & 40.9 & 40.8 \\
\hline \multicolumn{5}{|l|}{ Properties } \\
\hline Kinematic viscosity in a temp. of $100^{\circ} \mathrm{C}\left[\mathrm{mm}^{2} / \mathrm{s}\right]$ & 9.017 & 9.040 & 5.350 & 5.217 \\
\hline Kinematic viscosity in a temp. of $70^{\circ} \mathrm{C}\left[\mathrm{mm}^{2} / \mathrm{s}\right]$ & 20.32 & 20.38 & - & - \\
\hline Kinematic viscosity in a temp. of $50^{\circ} \mathrm{C}\left[\mathrm{mm}^{2} / \mathrm{s}\right]$ & - & - & 19.87 & 19.18 \\
\hline Kinematic viscosity in a temp. of $40^{\circ} \mathrm{C}$, converted $\left[\mathrm{mm}^{2} / \mathrm{s}\right]$ & 65.29 & 65.90 & - & - \\
\hline Viscosity index & 114 & 113 & 119 & 119 \\
\hline Refractive index $n_{D}^{70}$ & 1.4500 & 1.4491 & 1.4476 & 1.4447 \\
\hline Colour & L3.0 & 2.5 & L2.0 & 1.5 \\
\hline Solidification temperature $\left[{ }^{\circ} \mathrm{C}\right]$ & 50.4 & 51.2 & 37.8 & 38.0 \\
\hline Sulphur content $[\%(\mathrm{~m} / \mathrm{m})]$ & 0.41 & 0.39 & 0.37 & 0.41 \\
\hline $\begin{array}{l}\text { Group composition }[\%(\mathrm{~m} / \mathrm{m})] \\
\text { - paraffin-naphthenes } \\
\text { - aromatics with } \mathrm{n}_{\mathrm{D}}^{20}<1.53 \\
\text { - aromatics with } \mathrm{n}_{\mathrm{D}}{ }^{20} 1.53-1.55 \\
\text { - aromatics with } \mathrm{n}_{\mathrm{D}}{ }^{20} 1.55-1.59 \\
\text { - aromatics with } \mathrm{n}_{\mathrm{D}}{ }^{20}>1.59 \\
\text { - resins }\end{array}$ & $\begin{array}{c}81.7 \\
16.6 \\
<0.1 \\
<0.1 \\
<0.1 \\
1.4\end{array}$ & $\begin{array}{l}81.8 \\
16.4 \\
<0.1 \\
<0.1 \\
<0.1 \\
1.2\end{array}$ & $\begin{array}{c}84.4 \\
11.8 \\
<0.1 \\
<0.1 \\
<0.1 \\
2.9\end{array}$ & $\begin{array}{c}82.8 \\
14.0 \\
<0.1 \\
<0.1 \\
<0.1 \\
2.9\end{array}$ \\
\hline
\end{tabular}

of formamide, processes R 1378 and R 1379 for the heavier fraction $80 / \mathrm{Bl}$, there is a noticeable increase in the efficiency of raffinate by $3.4 \%(\mathrm{~m} / \mathrm{m})$ for a process using a co-solvent. In a raffinate produced from fraction $80 / \mathrm{Bl}$ during a process with no participation of a co-solvent, kinematic viscosity in $100^{\circ} \mathrm{C}$ was determined at $9.017 \mathrm{~mm}^{2} / \mathrm{s}$ and $65.29 \mathrm{~mm}^{2} / \mathrm{s}$ for $40^{\circ} \mathrm{C}$ recalculated from the value obtained in $70^{\circ} \mathrm{C}$; a viscosity index of 114 was determined based on these values. Raffinate R 1379 produced during the process using a co-solvent was characterised by slightly higher viscosities of $9.040 \mathrm{~mm}^{2} / \mathrm{s}$ in $100^{\circ} \mathrm{C}$ and $65.90 \mathrm{~mm}^{2} / \mathrm{s}$ in $40^{\circ} \mathrm{C}$, respectively; the viscosity index for this raffinate amounted to 113 . It was also characterised by a slightly lower viscosity index, a lower refractive index and a slightly better colour compared to the raffinate resulting from process $\mathrm{R} 1378$.

In the case of the lighter fraction 79/Bl, no increase in raffinate efficiency was noticed in the process using a co-solvent (process R 1381) compared to the process conducted using just $\mathrm{N}$-methylpyrrolidone (process R 1380). The viscosity index for both processes was calculated at an identical level and it amounted to 119 . Viscosities determined for raffinate generated in a process using $5 \%$ formamide were slightly lower in both temperatures compared to viscosities determined in the reference raffinate with just $\mathrm{N}$-methylpyrrolidone. A slight decrease in the refractive index and a colour improvement were recorded for process R 1381 which used NMP $+5 \%$ formamide. Figure 3 below presents the efficiencies of raffinates for the tested refining processes.

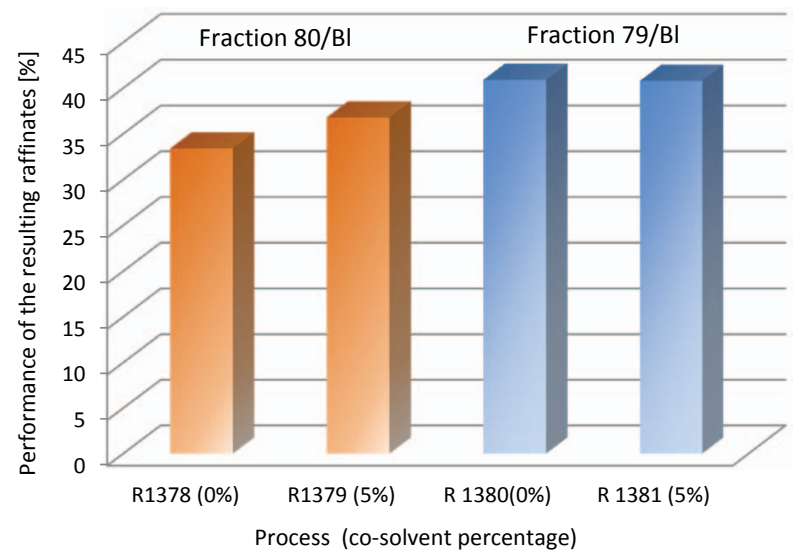

Fig. 3. Performances of raffinates in relations of the co-solvent amount for both fractions

Rys. 3. Wydajności rafinatów w zależności od udziału współrozpuszczalnika dla obu frakcji 
The refractive index in $70^{\circ} \mathrm{C}$ indicates an improvement in the quality of raffinates resulting from extraction processes using a cosolvent. For the reference raffinate for fractions $80 / \mathrm{Bl}$ from process R 1378, the value of the refractive index was 1.4500; in a comparable process resulting from refining based on the same feedstock with the participation of a co-solvent, the refractive index dropped by 0.0009 . Like in previous processes, in raffinates produced during the process for fraction $79 / \mathrm{Bl}$, the value of the refractive index in $70^{\circ} \mathrm{C}$ was also decreased by 0.0029 for the process using a co-solvent, and it amounted to 1.4447 .

The assessment of the selectiveness of fNMP activity along with the used amount of co-solvent was additionally based on an analysis of group compositions of the resulting raffinates. The test was performed using the PN-72/C-04025 method, which allows breaking aromatic hydrocarbons into groups depending on the values of the refractive index. Conventionally, it is assumed that aromatic hydrocarbons with a refractive index of $\mathrm{n}_{\mathrm{D}}{ }^{20}<1.53$ and $\mathrm{n}_{\mathrm{D}}^{20} 1.53-1.55$ define mono- and bicyclic compounds, while aromatic compounds with $\mathrm{n}_{\mathrm{D}}{ }^{20}>1.55$ characterise tricyclic and polycyclic aromatic hydrocarbons.

The performance of all 4 refining processes resulted in the removal of hydrocarbons with refractive indices $\mathrm{n}_{\mathrm{D}}^{20}$ above 1.53 , meaning bicyclic, tricyclic and polycyclic aromatic hydrocarbons. When comparing raffinates generated during extraction processes for which the feedstock consisted of the heavier fraction $80 / \mathrm{Bl}$, it can be concluded that no differences were observed in the group composition of these raffinates; they were virtually identical. The group composition of raffinates produced based on the lighter fraction 79/Bl exhibited a slight drop by $1.6 \%(\mathrm{~m} / \mathrm{m})$ in the paraffinicnaphthenic hydrocarbon content which they were produced zostały wytworzone ined during their processing raffinates obtained from it $\mathrm{z}$ niego rafinatów
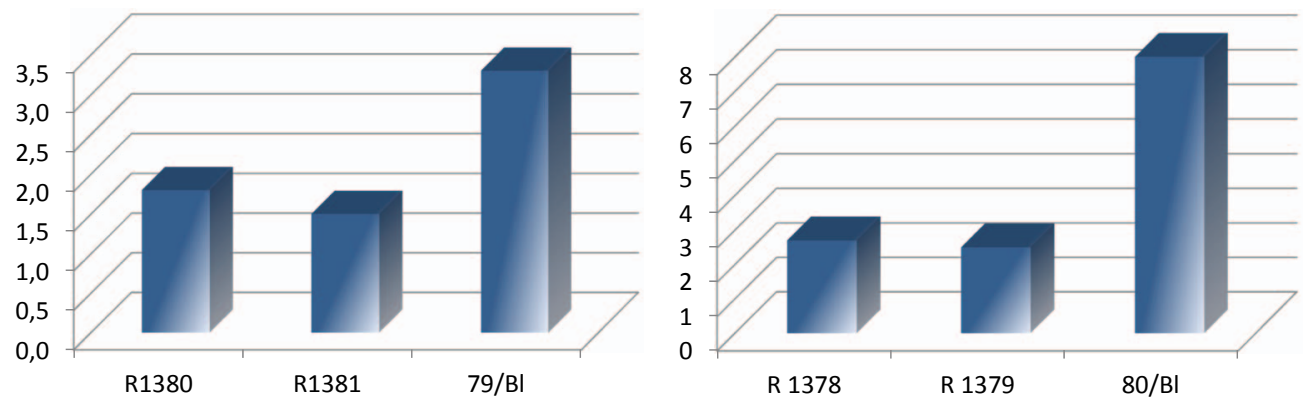

Fig. 4. Graphic presentation of the colour value determined in the raffinates and feedstock from

Rys. 4. Graficzne przedstawienie wartości barwy oznaczonej w rafinatach i surowcach, z których
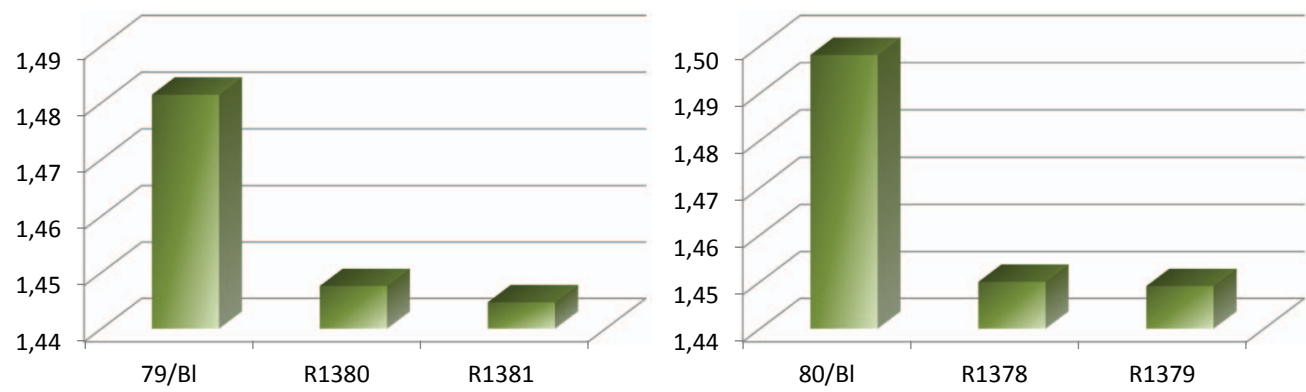

Fig. 5. Graphic representation of the refractive index at $70^{\circ} \mathrm{C}$ in the feedstock and raffinates obta-

Rys. 5. Graficzne przedstawienie wartości współczynnika załamania światła w $70^{\circ} \mathrm{C}$ w surowcach i rafinatach uzyskanych w trakcie ich przeróbki

for process R 1381 , and a $2.2 \%(\mathrm{~m} / \mathrm{m})$ increase in the level of aromatic hydrocarbons with a refractive index of $\mathrm{n}_{\mathrm{D}}{ }^{20}<1.53$.

For a better representation of the distribution of aromatic hydrocarbons contained in the resulting raffinates and feedstocks in specific groups, figures 6 and 7 present this distribution in a graphic form.

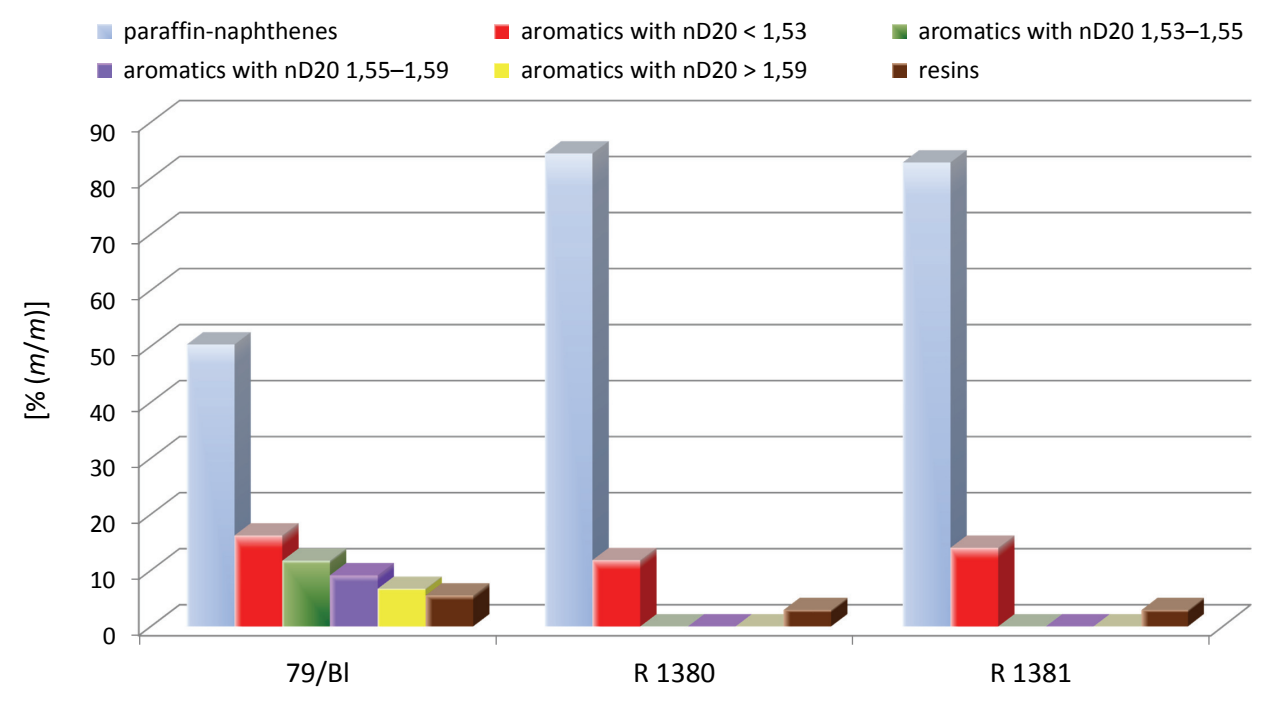

Fig. 6. Graphic presentation of the results of the group compositions of feedstock 79/B1, and the

Rys. 6. Graficzne przedstawienie wyników składów grupowych surowca 79/Bl oraz uzyskanych 


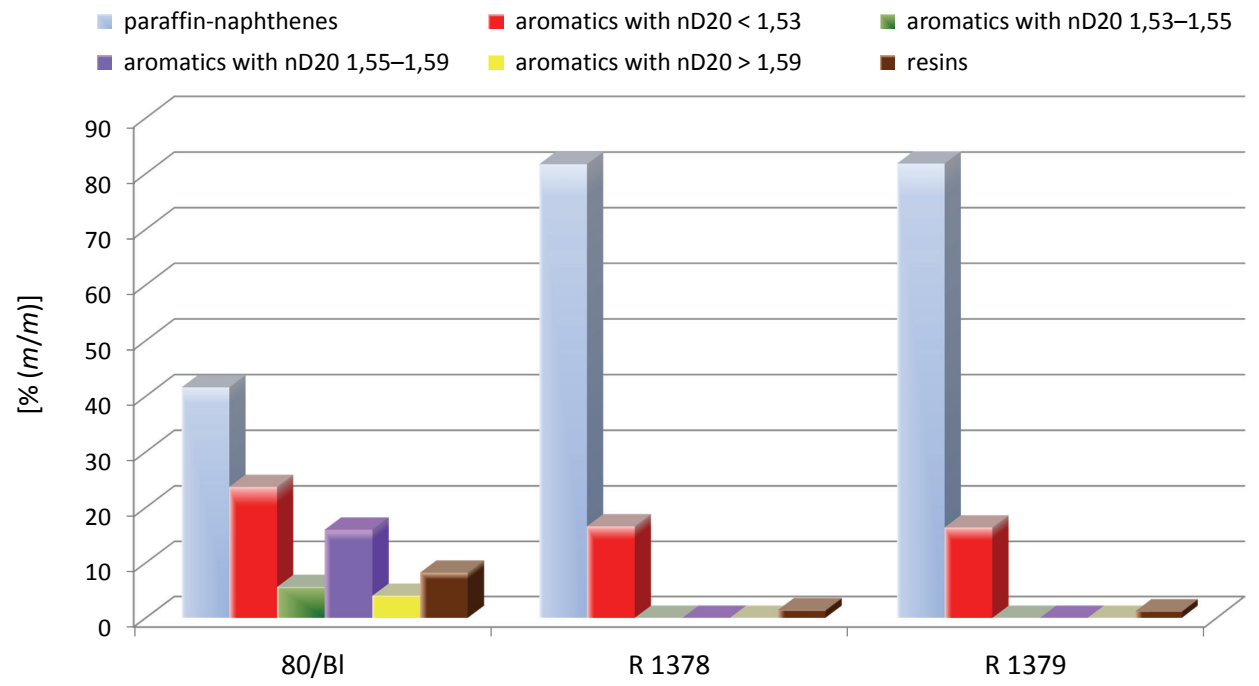

Fig. 7. Graphic presentation of the results of the group compositions of feedstock $80 / \mathrm{Bl}$, and the raffinates obtained from it

Rys. 7. Graficzne przedstawienie wyników składów grupowych surowca 80/B1 oraz uzyskanych z niego rafinatów

\section{Summary}

Solvent refining tests of specific vacuum fractions used technological parameters adjusted to critical temperatures determined for the given arrangements. Basic physicochemical properties of the produced raffinates were determined. When analysing the results produced in laboratory extraction processes for NMP and NMP with a 5\% addition of formamide, processes R 1378 and R 1379 for the heavier fraction 80/B1, there is a noticeable increase in the efficiency of raffinate by $3.4 \%(\mathrm{~m} / \mathrm{m})$ for the process using a co-solvent. However, it was characterised by a slightly lower viscosity index, a lower refractive index and a slightly better colour compared to the raffinate resulting from process $\mathrm{R} 1378$. No differences were observed in the group composition of the compared raffinates; they were generally identical. In the case of the lighter fraction $79 / \mathrm{Bl}$, no increase in raffinate efficiency was noticed in the process using a co-solvent (process R 1381) compared to the process conducted using just N-methylpyrrolidone (process $R$ 1380). The viscosity index for both processes was calculated at an identical level and it amounted to 119. A slight decrease in the refractive index and a colour improvement were recorded for process R 1381 which used NMP $+5 \%$ formamide. The group composition of the analysed raffinates exhibited a slight drop by $1.6 \%(\mathrm{~m} / \mathrm{m})$ in the paraffinic-naphthenic hydrocarbon content for process R 1381 , and a $2.2 \%(\mathrm{~m} / \mathrm{m})$ increase in the level of aromatic hydrocarbons with a refractive index of $\mathrm{n}_{\mathrm{D}}^{20}<1.53$.

When comparing the results produced in INiG - PIB with results presented in the literature regarding the use of a cosolvent in extraction processes, it should be remembered that vacuum fractions exhibit very diverse susceptibility to refining, depending on the petroleum from which they were acquired. The tests described in the papers were conducted in a periodic one-stage manner in laboratory glass. The tests performed in
INiG - PIB used a laboratory refining column, simulating the process of continuous solvent refining, which could have also affected the produced results.

This paper was written on the basis of the statutory work entitled: The impact of the use of a co-solvent in the extraction process on the quality of the resulting raffinates, pt. 2 - work of the Oil and Gas Institute - National Research Institute was commissioned by the Ministry of Science and Higher Education; order number: 0017/TO/2019, archive number: DK-4100-0009/2019.

\section{References}

Abdul-Halim A.-K. M., Amal Khalid Shehab A.-R., 2008. Viscosity Index Improvement of Lubricating Oil Fraction (SAE - 30). Iraqi Journal of Chemical and Petroleum Engineering, 9(3): 51-57.

Antosz A., Ptak S., 2018. Wpływ zastosowania współrozpuszczalnika w procesie ekstrakcji na jakość uzyskanych rafinatów. Archiwum Instytutu Nafty i Gazu - Państwowego Instytutu Badawczego, Kraków, nr zlec. DK-4100-0072/2018.

Bartyzel A., 2010. Ocena wpływu zastosowania N-metylopirolidonu w procesie ekstrakcji ciągłej na jakość uzyskanych rafinatów i ekstraktów. Archiwum Instytutu Nafty i Gazu-Państwowego Instytutu Badawczego, Kraków, nr zlec. DK-4100-0086/2010.

Bartyzel A., 2011a. Badania laboratoryjne procesów ciągłej ekstrakcji rozpuszczalnikowej. Nafta-Gaz, 9: 661-666.

Bartyzel A., 2011b. Badania procesu ekstrakcji rozpuszczalnikowej wysokoaromatycznych surowców naftowych przy zastosowaniu różnych rozpuszczalników organicznych. Archiwum Instytutu Nafty i Gazu -Państwowego Instytutu Badawczego, Kraków,nr zlec. DK-4100-0079/2011.

Bartyzel A., 2012. Badanie selektywności rozpuszczalników organicznych stosowanych w procesach ciągłej ekstrakcji rozpuszczalnikowej wysokoaromatycznych olejów naftowych. Nafta-Gaz, 10: 693-698.

Epelle E., Lukman Y., Otaru A.J., 2016. A comparative study of the solvent powers of phenol, furfural and NMP in improving the viscosity index of spent lubricating oil. International Research Journal on Engineering, 3(1): 8-24. http://apexjournal.org/irje/ archive/2016/Apr/fulltext/Epelle\%20et\%20al.pdf (accessed in: September 2019).

Espada J.J., Coto B., van Grieken R., Moreno J.M., 2008. Simulation of pilot-plant extraction experiments to reduce the aromatic content 
from lubricating oil. Chem. Eng. Process. 47: 1398-1403. DOI: 10.1016/j.cep.2007.06.012.

Fakhr Hoseini S.M., Hatamipour M.S., Tavakkoli T., Montahaee A., 2009a. Experimental Liquid-Liquid Equilibrium of (Lube Cut + Furfural + 2,2,4triMethyl Pentane) Ternary System from $\mathrm{T}=323.15-343.15 \mathrm{~K}$ and Simulation with NRTL. Industrial \& Engineering Chemistry Research, 48: 9325-9330.

Fakhr Hoseini S.M., Tavakkoli T., Hatamipour M.S., 2009b. Extraction of aromatic hydrocarbons from lube oil using n-hexane as a co-solvent. Separation and Purification Technology, 66(1): 167-170. https://www.sciencedirect.com/science/article/pii/ S1383586608004504?via\%3Dihub_(accessed in: September 2019).

Gary J.H., Handwerk G.E., 2001. Petroleum Refining Technology and Economics. Marcel Dekker, Inc.: 287-302.

Ghafil A.A., 2010. Evolutionary of extraction base oils unit's efficiency utilizing mixed solvent. Hydrocarbon Process, 88(9): 155-160.

Hussein M., Amer A.A., Gaberah A.S., 2014. Used Lubricating Oils Re-Refining by Solvent Extraction. American Journal of Environmental Engineering and Science, 1(3): 44-50. https:// www.researchgate.net/publication/273386306_Used_lubricating_oils_re-refining_by_solvent_extraction (accessed in: October 2019).

Ibtehal K.S., Muslim A.Q., 2015. Extraction of Aromatic Hydrocarbons from Lube Oil Using Different Co-Solvent. Iraqi Journal of Chemical and Petroleum Engineering, 16(1): 79-90.

Kirk-Othmer, 2007. Kirk-Othmer Encyklopedia of Chemical Technology. Volume 25. $5^{\text {th }}$ edn. Wiley J. and Sons Inc., New York.

Luo T., Zhang L., Zhang C., Ma J., Xu Z., Sun X., Zhao S., 2018. Role of water as the co-solvent in eco-friendly processing oil extraction: Optimization from experimental data and theoretical approaches. Chemical Engineering Science, 183(29): 275-287. https://www.sciencedirect.com/science/article/pii/ S0009250918301337?via\%3Dihub_(accessed in: October 2019).

Lynch T.R., 2008. Process Chemistry of Lubricant Base Stocks. Taylor \& Francis Group, LLC: 141-168.

Pelc L., Wróblewska B., Dettloff R., Szewczyk A., Kaczmarczyk A., Sęk K., 1989. Badania nad rozeznaniem możliwości intensyfikacji procesu selektywnej rafinacji olejów dla G.Z.R. w wyniku zastąpienia furfurolu N-metylopirolidonem. Etap II. Archiwum Instytutu Nafty i Gazu-Państwowego Instytutu Badawczego, Kraków.

Pelc L., Wróblewska B., Dettloff R., Szewczyk A., Sęk K., 1988. Badania nad rozeznaniem możliwości intensyfikacji procesu selektywnej rafinacji olejów dla G.Z.R. w wyniku zastąpienia furfurolu N-metylopirolidonem. Etap I. Archiwum Instytutu Nafty i Gazu-Państwowego Instytutu Badawczego, Kraków.
Pillon L.Z., 2007. Interfacial Properties of Petroleum Products. Wyd. CRC Press, Taylor \& Francis Group, LLC.

Pirro D.M., Webster M., Daschner E., 2016. Lubrication Fundamentals. CRC Press. https://www.crcpress.com/rsc/ downloads/Ch2.10.1201_b19217-9_\%281\%29.pdf_(accessed in: October 2019).

Sequeira A., 1989. Lubrication Base Oil Processing. Lubrication, 75(1): 5-16.

Sequeira A., 1992. Lubricating Oil Manufacturing Processes. Petroleum Processing Handbook, Marcel Dekker, New York: 634-664.

Speight J., 2015. Fouling in Refineries. Elsevier Store: 226-227.

Tanasescu C., Rosca P., 2001. Rafinacja olejów bazowych metodą ekstrakcji n-metylopirolidonem. Nafta-Gaz, 3: 153-159.

Wiley John and Sons; Kirk-Othmer Encyklopedia of Chemical Technology, New York 2007: 28.

Yousef N.S., Ahmed Muhammad A., 2018. Dearomatization of lube oil using polar solvents. International Journal of Scientific \& Engineering Research, Vol. 9 (3) https://www.ijser.org/researchpaper/Dearomatization-of-lube-oil-using-polar-solvents. pdf (accessed in: October 2019).

\section{Patents}

Patent CN105542834 (A) Composite solvent for extraction distillation separation of aromatic hydrocarbons, and applications thereof. Publ. 4 May 2016.

Patent IN39MU2014 (A) A process for the selective aromatic extraction from hydrocarbon feed stocks using mixed solvent system. Publ. 21 August 2015.

Patent US2003100813 Extraction of aromatics from hydrocarbon oil using furfural co-solvent extraction process. Publ. 29 May 2003.

Patent US2010243533 Extraction of aromatics from hydrocarbon oil using n-methyl2-pyrrolidone and co-solvent. Publ. 30 September 2010.

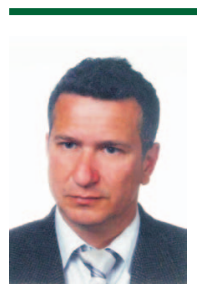

Artur ANTOSZ M.Sc. Eng.

Senior Research and Technical Specialist at the Department of Oils, Lubricants and Bitumen Oil and Gas Institute - National Research Institute 25 A Lubicz St.

31-503 Krakow

E-mail: artur.antosz@inig.pl 